\title{
Makna Pengurapan Menurut 1 Yohanes 2:20, 27
}

\author{
Triyono Surahmiyoto \\ Sekolah Tinggi Teologi Kalimantan \\ Korespondensi: triyonosurahmiyoto@sttkalimantan.ac.id
}

\begin{abstract}
Abstrak
Judul bahasan adalah Makna Pengurapan Menurut 1 Yohanes 2:20, 27. Latar belakang pembahasan adalah adanya kesamaran penggunan istilah pengurapan dalam kehidupan masyarakat Kristen baik dalam percakapan maupun dalam doa- doa yang diucapkan secara samar. Kesamaran dan kerancuan dalam pemahaman tentang pengurapan cenderung menimbulkan perilaku yang tidak diharapkan dalam kehidupan masyarakat Kristen. Penyimpangan dan penyesatan bahkan perpecahan, perpindahan serta kecurigaan antar sesama orang percaya dapat terjadi dalam kehidupan masyarakat Kristen. Bertolak dengan hal tersebut maka penulis berusaha menelusuri penggunaan istilah pengurapan tersebut khususnya dalam Perjanjian Baru. Penulis menemukan istilah pengurapan dalam 1 Yohanes 2:20. Dengan menggunakan metode penafsiran induktif: literal, gramatikal, kontekstual, historikal, dan teologi serta memperhatikan pandangan beberapa penafsir penulis menemukan bahwa pengurapan yang dimaksud ternyata digunakan secara konotatif untuk menggambarkan pertolongan Roh Kudus dalam hidup setiap orang percaya. Pengurapan erat berhubungan dengan pengajaran dan kebenaran ajaran. Pengurapan sekali terjadi dan bersifat permanen dalam sepanjang hidup orang yang percaya. Pengurapan ini identik dengan pemeteraian dan pendiaman Roh Kudus dalam kehidupan orang percaya. Pengurapan dalam 1 Yohanes 2:20 adalah krisma. Krisma ini adalah kata benda dan menunjuk kepada minyak yang digunakan dalam peristiwa pengurapan. Yohanes menyatakan bahwa orang percaya sudah dan sedang menerima krisma yaitu minyak urapan dalam rentang kehidupannya. Dengan demikian sebenarnya orang percaya tidak perlu berulang-ulang meminta dan mengharapkan terjadinya pengurapan dalam kehidupannya. Orang percaya perlu mengimani bahwa pengurapan Allah sudah dan sedang terjadi serta menuntun setiap orang percaya dalam kehidupan yang benar sebagai orang yang sudah percaya bahwa Yesus itu Tuhan
\end{abstract}

Kata-kata kunci: Pengurapan, Roh Kudus, Pengajaran

\begin{abstract}
The study is entitled The Meaning of Anointing According to 1 John 2:20, 27. The background of this study is the obscurity found in the usage of the term anointing among Christians, whether in casual conversation or in prayer in which the purpose is uncertain. The obscurity and ambiguity in the undertanding of anointment tend to result in unrighteous behaviour in Christian life. Based on that issue the writer undretook to do research of the usage of the term concerned especially in the New Testament. The writer have found the usage of the term in 1 John 2:20. By using inductive interpretation method: literal, grammatical, contextual, historical, and theological and also do observations through multiple interpretations comparison, the writer has found that the anointment is refered to be used conotatively to depict the help from the Holy Spirit in every believer's life. This anointment is closely related to teaching and the righteousness of teaching. The anointment happens once and permanent in a believer's only life. This is identical to sealing and the Holy Spirit that resided in the believers. The anointing in 1 John 2:20 is chrism. Chrism is a noun refers to the oil that is used in an anointing event. John states that a believer is already and receiving the chrism - the anointing oil - in the believer's running life. Believers need to believe that God's anointing has been done, is happening, reside to be with every believer in righteous life as a person who believes that Jesus is God.
\end{abstract}

Keywords: Anointing, Holy Spirit, Teaching. 


\section{Pendahuluan}

Penggunaan istilah berkenaan dengan pengurapan dalam Perjanjian Baru sangan sedikit. Dalam Perjanjian Baru istilah pengurapan hanya diketemukan dalam ruang lingkup pembahasan ini, yaitu dalam I Yohanes 2:20,27 digunakan sebanyak tiga kali. Oleh karena itu untuk mengungkap makna istilah tersebut diperlukan pembahasan berdasarkan kontek dekat dalam bagian tersebut. Penulis berusaha mengungkap masalah tersebut berdasarkan pengamatan induktif dalam kontek ini.

\section{Pengurapan adalah Krisma}

Yohanes mengatakan, "Tetapi kamu telah beroleh pengurapan dari Yang Kudus..." (1 Yoh 2:20). Istilah yang diterjemahkan "pengurapan" dalam bahasa Indonesia adalah berasal dari istilah Yunani (krisma). ${ }^{1}$ Hal ini menimbulkan satu masalah yaitu siapa yang dimaksud dengan istilah krisma. Para ahli teologi berbeda pandangan terhadap masalah ini. Satu pihak berpendapat bahwa krisma adalah kiasan untuk Firman Allah, tetapi pihak lain berpendapat bahwa krisma adalah kiasan untuk pendiaman Roh Kudus.

\section{Pandangan:}

Krisma Kiasan Firman Allah

Gramberg dan C.H. Dodd menyatakan bahwa krisma menunjuk kepada Firman Allah yang dinyatakan kepada orang-orang yang percaya; itulah yang menjadi urapan yang kuasanya tinggal tetap... Untuk Yahya bukanlah kata-kata saja Firman Allah itu, tetapi suatu kuasa, suatu kenyataan, suatu urapan yang diberikan dari mulanya. Kalau Firman Allah itu tetap di dalam hati kita, maka kita tidak akan tertarik kepada pengajaran yang sesat. ${ }^{2}$

${ }^{1}$ Kurt Aland, The Greek New Testament, Ed. Mathew Black, Carlo M. Martini, Bruce M. Metsger, Aland Wikgren, (Germany: Biblia-Druck BnbH Stuugart, 1983), 817.

${ }^{2}$ Ds. Th. B.W.G Gramberg, Tafsiran Surat-surat Yahya, (Bandung: Nilakandi, 1967), 85.
Pandangan tersebut didasarkan kepada perkataan Tuhan Yesus dalam Yohanes 15:7 yaitu: "Jikalau kamu tetap tinggal di dalam Aku, dan perkataanKu tetap di dalam kamu, mintalah apa yang kamu kehendaki itu akan dikaruniakan kepadamu kelak." 3 Berdasarkan alasan tersebut Gramberg berpendapat bahwa krisma adalah kata kiasan untuk Firman Allah.

Marshal mengutip pendapat C.H. Dodd menyatakan bahwa krisma menunjuk kepada Firman Allah yang mengajar kebenaran kepada orang-orang percaya dan yang secara obyektif di dalamnya bersaksi kepada kebenaran. Sebab mereka telah menerima Firman Allah, orangorang percaya yang benar datang kepada pengetahuan kebenaran dan selanjutnya mereka mempunyai penangkal kepada pengajar sesat. ${ }^{4}$

Apabila krisma dipandang sebagai kiasan untuk Firman Allah, ada masalah yang menjadikan pendapat tersebut kurang tepat. Pertama, dalam Alkitab minyak biasa digunakan sebagai tipe daripada Roh Kudus (Luk4:18). J. Oswald Sanders menyatakan penyebutan Roh Kudus dengan langsung sebagai minyak dapat diketahui dari beberapa ayat seperti Lukas 4:18, Kisah Para Rasul 4:27 dan 10:38 di mana Roh Kudus disebut minyak urapan berkenaan dengan pengurapan Tuhan Yesus. John F. Walvoord juga menyatakan minyak digunakan sebagai sebuah tipe dari Roh, dan kehadiran Roh adalah hasil dari pengurapan, bahkan setiap referensi yang menunjuk kepada pengurapan oleh Roh, minyak sebagai tipenya. ${ }^{6}$ Kedua, dalam Efesus 6:17 Paulus menegaskan bahwa firman Allah adalah pedang Roh. Dalam I Korintus 12:3, Paulus mengingatkan bahwa tidak ada seorangpun yang dapat mengaku bahwa Yesus adalah Tuhan selain karena Roh Kudus. Roh Kuduslah yang mengajar dan menyatakan segala kebenaran kepada orang percaya (I Korintus 2:10,13). Yesus mengajarkan bahwa Roh Kuduslah yang akan mengajarkan segala sesuatu

${ }^{3}$ Ibid.

${ }^{4}$ Marshal, Epistle of John, 154.

${ }^{5}$ J. Oswald Sanders, Roh Kudus Penolong Kita, pen. Alma E. Tobing, (Jakarta: Badan Penerbit Kristen, 1965), 25.

${ }^{6}$ John F. Walvoord, The Holy Spirit, Ed. 3, (Grand Rapids: Zondervan Publishing House, 1988), 155. 
dan mengingatkan terhadap semua yang telah dikatakan Yesus (Yohanes 14:26).

\section{Pandangan:}

Krisma Kiasan Roh Kudus

Vine berkata bahwa krisma dalam Perjanjian Baru hanya digunakan sebagai kiasan untuk Roh Kudus. ${ }^{7}$ Krisma itu adalah Roh Kudus yang hadir dan diam melayani orang percaya dari Bapa melalui Anak yaitu Yesus Kristus. ${ }^{8}$ Herbert juga setuju bahwa krisma adalah kiasan untuk pendiaman Roh Kudus dan Pengetahuan. ${ }^{9}$ Demikian pula Cremer menyatakan bahwa krisma berarti sebuah minyak urapan yang dialami, suatu hubungan dan resepsi dari Roh Kudus, istilah itu adalah kiasan untuk Roh Kudus. ${ }^{10}$

Krisma digunakan sebagai kata benda, akusatif, tunggal, netral. ${ }^{11}$ Arti literal kata krisma adalah minyak urapan. ${ }^{12}$ Krisma lebih tepat dimengerti sebagai kiasan untuk Roh Kudus. Oswald J. Sanders menegaskan bahwa dalam I Yohanes 2:20,27 serta I Korintus 1:21, penjelasan berkenaan dengan Roh Kudus sebagai minyak urapan untuk semua orang percaya. ${ }^{13}$

Kata krisma digunakan sebagai akusatif yang berfungsi untuk membatasi suatu tindakan yang dinyatakan oleh kata kerja sebelumnya yaitu

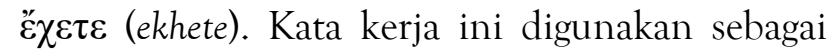
kata kerja, kini, aktif, indikatif, dari kata $\varepsilon^{\prime} \chi \omega$

${ }^{7}$ W.E. Vine, Expository Dictionary of The New Testament Words, (Grand Rapids: Zondervan Publishing House, t.t), 59.

${ }^{8}$ Robert B. Girdlestone, Synonims of The New Testament, (Grand Rapids: Wm. B. Eerdmans Publishing Company, 1981), 184.

${ }^{9}$ Livingstone G. Herbert, “anoint," Wiclif Bible Encyclopedia, Ed. Howard F., Vol. I, (Chicago: Moody Press, 1975), 100.

${ }^{10}$ Hermann Cremer, Biblico-Theological Lexicon of The New Testament, (Edinburg: T \& T Clark, 1985), 579.

${ }^{11}$ Barbara Friberg dan Timothy Friberg, Analytical Greek New Testament, (Grand Rapids: Bakker Book House, 1982), 723-4.

${ }^{12}$ Walter Bauer, William F. Arndt, F. Wilbur Gingrich, Greek English Lexicon of The New Testament, Chicago: The University of Chicago Press, 1979, 886.

${ }^{13}$ Sanders, Roh Kudus Penolong, 25. $(e k h \bar{o}) .{ }^{14}$ Dalam bahasa Yunani istilah tersebut sebenarnya dapat berarti "mempunyai atau memiliki." 15 Karena itu frasa "kamu telah beroleh pengurapan" sebenarnya dapat diterjemahkan menjadi "kamu sedang mempunyai, memiliki pengurapan.” Sifat khusus dari krisma, adalah hanya satu dan menjadi milik semua orang percaya dalam setiap waktu.

Dalam ayat 27, kata krisma digunakan dua kali sebagai kata benda, nominatif, netral, tunggal. ${ }^{16}$ Sebagai nominatif maka berfungsi sebagai subyek kalimat atau klausa dalam ayat

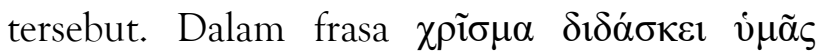
(khrisma didaskei humas), nampak kata krisma diikuti dengan kata kerja didaskei yang digunakan sebagai kata kerja kini, aktif, indikatif, orang

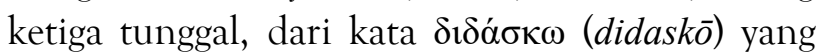
artinya mengajar. ${ }^{17}$ Dalam bentuk aktif, maka fungsi kata krisma adalah sebagai pelaku dan dalam bentuk kala kini, itu berarti tindakannya sedang berlangsung terjadi. Krisma itu sedang berlangsung melakukan perbuatan mengajar. Krisma yang adalah minyak urapan, namun mempunyai kemampuan untuk mengajar orang percaya dalam kebenaran, suatu pekerjaan yang dikerjakan oleh Roh Kudus (Yoh 16:13; I Kor 2:10-13).

Krisma memang cocok sebagai kiasan untuk Roh Kudus. Kepada jemaat di Korintus Paulus menyejajarkan pengurapan dengan pekerjaan Roh Kudus yang lain (2 Kor 1:21,22).

Dalam Lukas 4:18 dan KPR. 10:38, Lukas menyatakan bahwa Roh Kudus yang menjadi minyak urapan. Kata kerja yang digunakan adalah sama dengan kata yang digunakan dalam I Korintus 1:21. Ketiganya mempunyai akar kata chrio dalam bahasa Yunani, di mana dalam penggunaannya selalu berkaitan langsung dengan peranan Roh Kudus. ${ }^{18}$ Krisma menyatakan fungsi pekerjaan Roh Kudus dalam

${ }^{14}$ Nathan Hans, Merrile C. Tenny, A Parsing Guide to The Greek of New Testament, (Ontario: Herald Press, 1971), 429.

${ }^{15}$ Bauer, Arndt, Gingrich, Greek Lexicon, 887.

${ }^{16}$ Friberg, Analytical Greek, 723.

${ }^{17}$ Hans, Tenney, A Parsing Greek, 428.

${ }^{18}$ Law Rence o. Ricards, Expository Dictionary of Bible Words, (Grand Rapids: Zondervan Publising House, 1975), 54. 
hubungannya dengan kemampuan orang percaya untuk dapat memahami ajaran yang benar bahwa Yesus adalah Anak Allah. ${ }^{19}$ Yohanes mengingatkan jemaat bahwa mereka sedang mempunyai pengurapan yang benar dari Allah (2:20,27). Sebagai tandanya adalah pengetahuan yang diperoleh dari pengajaranNya yaitu kebenaran bahwa Yesus adalah Anak Allah. Pengurapan bukan sekedar mistik yang membawa kepada pengetahuan yang tinggi dari dunia lain dan sebagai cara penebusan. ${ }^{20}$ Pengurapan bukan sekedar salah satu bagian dari upacara permulaan masuk agama misteri yang mana seseorang dianggap benar untuk menambah pengetahuan khusus dan hubungan khusus dengan Allah. ${ }^{21}$ Memang guru-guru palsu menuntut bahwa mereka telah mempunyai sebuah pengurapan khusus yang memberi mereka sebuah pengetahuan khusus dari Allah. ${ }^{22}$ Bahkan guru-guru palsu menganggapnya bahwa pengetahuan itu adalah kepunyaan segolongan orang yang terpilih karena mereka masuk ke dalam upacara rahasia (pengurapan) dan makrifat itu tidak pernah akan menjadi milik orang Kristen. ${ }^{23}$ Pengurapan adalah Roh Kudus yang Allah berikan kepada setiap orang percaya pada waktu kelahiran kembali bukan secara temporal, tetapi sebagai Pribadi yang terus mendiami orang percaya dan memberikan hikmat untuk mengetahui dan meyakini kebenaran Firman Allah. ${ }^{24}$ Dengan pengurapan ini orang percaya mempunyai kemampuan untuk meyakini bahwa Yesus adalah Allah (I Kor 12:3). Akhirnya Muller menegaskan bahwa untuk Yohanes krisma adalah Roh Kebenaran yang memberikan orang-orang percaya kuasa pengetahuan, sehingga mereka tidak membutuhkan pengajar yang lain. Melalui pengurapan, mereka telah menerima Roh yang

${ }^{19}$ Robert S. Candlis, The First Epistle of John, (Grand Rapids: Zondervan Publishing House, t.t), 196.

${ }^{20} \mathrm{D}$. Muller, "Anoint," The New International Dictionary of The New Testament Theology, Ed. Collin Brown (Grand Rapids: Zondervan Publising House, 1975), 123.

${ }^{21}$ William Barclay, The Letter of John and Jude,

${ }^{22}$ Ibid.

${ }^{23}$ Gramberg, Tafsiran Surat Yahya, 79.

${ }^{24}$ Kenneth S. Wuest, Wuest's Word Studies, Vol. 3, (Wm. B. Eerdmans Publishing Company, 1969), 125. membawa kepada gagasan apa yang Yesus katakan dalam Yohanes 16:13. ${ }^{25}$ Mitchel menyatakan bahwa Roh Kudus yang adalah penulis Alkitab mendiami setiap orang percaya, Dia memimpin dan menuntun orang percaya ke dalam semua kebenaran dan menjaga kita dari perkara dusta, dan memungkinkan kita untuk membandingkan perkara rohani dan duniawi (Yoh 16:13; I Kor 1:13). ${ }^{26}$

Istilah krisma memang merupakan istilah yang pada mulanya biasa digunakan dalam peristiwa pengurapan. Yohanes menggunakan istilah tersebut sebagai kiasan untuk Roh Kudus

\section{Pengurapan dari Yang Kudus}

Pengurapan berasal dari Yang Kudus. Menurut Donald W. Burdick, istilah Yang Kudus adalah menunjuk kepada Allah. Ia mengatakan bahwa mereka telah diurapi dengan sebuah minyak urap yang berasal dari Allah, pengurapan ini tidak datang dari Roh Kudus, malahan itu adalah Roh Kudus yang Allah Bapa kirim. ${ }^{27}$ Pandangan yang lain mengatakan "Yang Kudus adalah Kristus yang diriNya sendiri sebagai Kristus yang diurapi." ${ }^{28}$ William Alexander D.D. juga menyatakan "kamu mempunyai krisma dari Yesus Kristus." 29

Pendapat selanjutnya berpendapat bahwa Yang Kudus adalah penamaan yang tidak begitu lumrah, namun tidak disangsikan bahwa ia menunjuk kepada Roh Kudus, pengurapan itu adalah karunia Roh Kudus. ${ }^{30}$ Tetapi ada juga yang berpendapat bahwa Kristus bukan sebagai sumber pengurapan melainkan sebagai pelaku yang melaksanakan pengurapan. Sehingga dalam ayat 20 dapat diterjemahkan sebagai berikut: "Tetapi kamu telah mempunyai Roh Kudus yang

${ }^{25}$ Muller, 123.

${ }^{26}$ John G. Mitchel, Fellowship Three Letters From John, (Porland: Multnomah Press, 1979), 74.

${ }^{27}$ Donald W. Burdick, The Epistle of John, (Chicago: Moody Press, 1970), 42.

${ }^{28}$ Candlish, Epistle of John, 166

${ }^{29}$ William Aleksander, The Epistle St. John, (London: Hodder and Stoughton, t.t), 169.

${ }^{30}$ Leon Morris, "Tafsiran I Yohanes," Tafsiran Alkitab Masa Kini, (Jakarta: BPK Gunung Mulia, 1983), 897. 
dicurahkan pada kamu oleh Yesus Kristus dan kamu semua mengetahui kebenaran." 31 Pandangan ini selaras dengan versi Alkitab Kabar Baik Masa Kini dengan mengatakan, "Tetapi kalian sudah menerima Roh Allah yang sudah dicurahkan oleh Yesus Kristus." 32 Itulah beberapa pandangan yang muncul sehubungan dengan penggunaan istilah Yang Kudus dalam I Yohanes 2:20.

Dalam bahasa Yunani kata yang digunakan

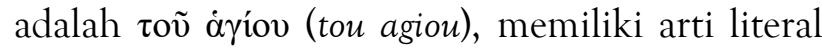
bervariasi. Istilah tersebut dapat berarti kudus, murni, suci maupun sempurna. ${ }^{33}$ Menurut Liddel dan Scott, istilah tersebut dapat mengungkapkan kepercayaan kepada para dewa. ${ }^{34}$ Dalam arti secara positif kata tersebut memang dapat mempunyai arti kudus, suci seperti untuk Bait, di mana merupakan tempat yang dipisahkan untuk Yang Maha Kudus. Demikian juga untuk orang, kata tersebut dapat berarti kudus, murni dan saleh. Tetapi dalam arti negatif, istilah tersebut dalam penggunaannya dapat berarti terkutuk, keparat, buruk sekali, dan keterlaluan. ${ }^{35}$ Dalam arti ini, istilah tersebut mengungkapkan perbuatan yang sifatnya sangat keterlaluan jeleknya. Namun pada umumnya istilah tersebut digunakan unutk mengungkapkan kualitas yang dimiliki oleh benda-benda atau pribadi-pribadi yang mendekati suatu sifat ilahi. ${ }^{36}$ Dalam hal ini penggunaan kata agiou untuk mengungkap-kan kualitas kesucian dari suatu benda atau pribadi yang mendekati kekudusan dan kesucian Allah.

Dalam I Yohanes kata tou agiou digunakan sebagai adjectif pronominal, genetif, maskulin, tunggal dengan artikel penentu genetif, maskulin, tunggal. ${ }^{37}$ Kata tou agiou adalah kata yang berdiri sendiri sebagai genetif substansif,

${ }^{31}$ Good News Bible Today's English Version, (t.t: United Bible Societies, 1990), 299.

${ }^{32}$ Alkitab Kabar Baik untuk Masa Kini, (Jakarta: Lembaga Alkitab Indonesia, 1978), 618.

${ }^{33}$ Bauer, Arndt, Gingrich, Greek Lexicon, 9.

${ }^{34}$ Liddel, Scott, Greek Lexicon. P. 9.

${ }^{35}$ Ibid.

${ }^{36}$ Barclay M. Newman Jr., Greek English Dictionary of The New Testament, (London: United Bible Societies, 1971), 2.

${ }^{37}$ Friberg, Analytical Greek, 723. karena kata tersebut mempunyai artikel namun tidak ada kata lain yang sepadan dengan kata tersebut dalam hal kasus, jenis dan jumlahnya dalam ayat 20. Karena itu kata tersebut dapat diterjemahkan "Yang Kudus."

Kata tou agiou dapat menunjuk kepada dua kemungkinan. Pertama, menunjuk kepada Allah Bapa (I Yoh 2:20). Kedua, menunjuk kepada Tuhan Yesus Kristus (Kis 3:14). ${ }^{38}$ Apabila menunjuk kepada Allah Bapa memungkinkan karena kekudusan adalah karakterNya (I Pet 1:16). Tetapi dapat menunjuk kepada Yesus Kristus karena sifat kekudusan juga menjadi karakterNya, yang mutlak dimiliki dalam diriNya (Mrk 1:24).

Dalam buku-bukunya yang lain Yohanes sering mengunakan istilah tersebut untuk menunjuk kepada Yesus (Yohanes 6:69; Wahyu 3:7). Lukas juga menggunakan istilah Yang Kudus untuk menunjuk kepada Yesus Kristus (Lukas 4:34, Kis 3:14). Penggunaan istilah Yang Kudus juga terdapat dalam tulisan Markus. Ia mencatat juga pengakuan setan terhadap keberadaan Yesus sebagai Yang Kudus dari Allah (Mrk 1:24). Berdasarkan fakta tersebut memang memungkinkan sebutan Yang Kudus dalam I Yohanes 2:20 untuk menunjuk kepada Tuhan Yesus. Paulus menegaskan bahwa Allah adalah pelaku dari pada peristiwa berlangsungnya pengurapan terhadap orang-orang percaya, dan karena itu Dia yang menjadi sumber pengurapan (I Korintus 1:21).

Penggunaan kata tou agiou didahului dengan kata $\dot{\alpha} \pi$ (apo). Kata tersebut mempunyai pengertian dasar pemisah dari seseorang atau sesuatu yang lain. ${ }^{39}$ Dalam bahas Yunani klasik, kata tersebut hanya digunakan sebagai kata depan dengan genetif, arti dasarnya dari. ${ }^{40}$ Kata tersebut dapat menyatakan asal-usul atau sebab munculnya suatu tindakan seperti: dari atau oleh siapa tindakan terjadi; oleh siapa tindakan itu dilakukan; kebanyakan untuk menyatakan sebuah agen yang kurang langsung. ${ }^{41}$ Sedangkan

\footnotetext{
${ }^{38}$ Bauer, Arndt, Gingrich, Greek Lexicon, 9.

${ }^{39}$ Ibid., 86.

${ }^{40}$ Henry Gerge Liddel, Robert Scott, Greek English Lexicon, (New York: American Book Company, t.t), 174.

${ }^{41}$ Ibid
} 
dalam Perjanjian Baru, kata tersebut dapat digunakan dalam berbagai macam arti namun semuanya bertolak pada arti dasar "dari" dan sering mengungkapkan gagasan pemisahan dari tempat, waktu, orang maupun sesuatu yang lain. ${ }^{42}$ Hubungan orang percaya dengan Allah adalah hubungan dalam Yesus Kristus dan perbuatan Allah terhadap umatNya juga dilaksanakan di dalam Tuhan Yesus. Dengan demikian sebutan Yang Kudus dalam I Yohanes 2:20, lebih cocok digunakan untuk menunjuk kepada pribadi Allah Bapa, sebagaimana pendapat Baur, Arndt dan Gingrich yang menjelaskan bahwa Yang Kudus dalam I Yohanes adalah menunjuk kepada Allah Bapa. ${ }^{43}$

Yohanes menggunakan istilah Yang Kudus adalah untuk menunjuk kepada pribadi Allah. Dia adalah Allah yang mempunyai hakekat kudus, sebagaimana yang diungkapkan dalam arti literal kata. Di samping itu dalam penggunaan sebagai genetif substantif membuktikan bahwa istilah tersebut menunjuk kepada Allah.

\section{Pengurapan untuk Semua Orang Percaya}

Pengurapan itu untuk semua orang percaya. Pengurapan ini bukan hanya dilakukan terhadap orang-orang tertentu yang memenuhi kriteriakriteria tertentu dan dipilih untuk melaksanakan tugas-tugas khusus sebagaimana dalam Perjanjian Lama. Pengurapan ini bukan hanya untuk kaum laki-laki saja dalam gereja dan sebaliknya juga bukan hanya untuk kaum perempuan saja. Pengurapan ini juga bukan hanya untuk anggotaanggota gereja yang telah memenuh persyaratanpersyaratan tertentu sebagaimana yang ditetapkan oleh gereja. ${ }^{44}$ Pengurapan adalah untuk semua orang percaya kepada Allah di dalam Yesus tanpa terkecuali. Kata $\dot{v} \mu \varepsilon \mathbf{i} \varsigma$ (humeis) digunakan dalam ayat 20 dan 27 dalam bentuk yang sama yaitu sebagai kata benda, kata ganti orang, nominatif, orang kedua jamak. ${ }^{45}$

\footnotetext{
${ }^{42}$ Bauer, Arndt, Gingrich, Greek Lexicon, 86-7

${ }^{43}$ Ibid, 9.

${ }^{44}$ Ernest Mariyanto, Persiapan Krisma Suci, (Yogyakarta: Kanisius, 1985), 45.

${ }^{45}$ Friberg, Analytical, 723.
}

Artinya adalah kamu sekalian. ${ }^{46}$ Dalam

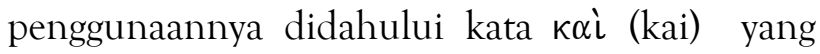
berarti "tetapi." 47 Kata kai menyatakan perbedaan tajam terhadap orang yang lain. Ada beberapa pandangan yang berbeda mengenai obyek pengurapan. Pertama, dari gereja Katolik. Gereja Katolik hingga kini, praktek pengurapan dengan sebuah minyak masih terus dilakukan. Pengurapan dilakukan terhadap anggota-anggota gereja yang telah memenuhi pesyaratan sebagaimana yang telah ditentukan oleh gereja. Dalam buku persiapan krisma suci didaftarkan beberapa persyaratan seperti: 1 . Sudah dibaptis, 2. Dalam keadaan rahmat, jika ada dosa perlu mengadakan pengakuan dosa, 3. Mengikuti persiapan sebagaimana yang ditetapkan gereja dan lain sebagainya. ${ }^{48}$ J. D. Crichton menyatakan tata cara krisma mengatakannya pada usia yang matang (aetas maturios) dan tidak dapat dikatakan secara tegas 8,9,10 atau 11 tahun. Di lain pihak ada beberapa orang yang menganggap usia akil balik sebagai paling cocok. Apakah juga ada kemungkinan menangguhkan umur krisma sampai 18 atau 19 tahun? Rasanya aneh! Pada umur itu orang sudah menikah. Masalah ini telah diperdebatkan selama lebih dari dua puluh lima tahun dan belum mencapai pemecahan yang memuaskan. ${ }^{49}$ Kedua, dari golongan Kharismatik. Morris Cerullo mengatakan bahwa, Saya menyampaikan terus Wahyu yang Tuhan telah berikan kepadaku di bawah urapan baru Roh Kudus. Dan saya yakin bahwa anda pun dapat merasakan urapan baru ini apabila anda telah membaca buku ini... Anda dapat menerima langsung urapan baru itu dari rumah anda sendiri... Anda dapat menggunakannya untuk melawan Iblis sampai ia lari tunggang langgang... di atas segala-galanya saya ingin Tuhan memberikan anda urapan baru dalam kehidupan anda... ${ }^{50}$ Keneth E. Hagin juga mengajarkan bahwa pengurapan merupakan penguasaan Allah oleh Roh Kudus terhadap

\footnotetext{
${ }^{46}$ Newman, 154.

${ }^{47}$ Ibid., 84.

${ }^{48}$ Mariyanto, Krisma Suci, 45.

${ }^{49}$ J.D. Crichton, Sakramen dan Krisma, (Yogyakarta:
} Kanisius, 1990), 108.

${ }^{50}$ Morris Cerullo, Urapan Baru, pen. Wimanjaya K. Liotohe, (Jakarta: Yayasan Pekabaran Injil, t.t), 178. 
setiap orang yang berbeda-beda satu dengan yang lain. Sebagian orang mendapatkan pengurapan untuk kesembuhan, dan yang lain Tuhan mengurapi untuk berkotbah, mengajar dan menduduki beraneka ragam jabatan. ${ }^{51}$ Masingmasing pengurapan dapat di perbedaannya sebagaimana orang mengenakan sebuah baju, di mana setiap baju dapat menimbulkan rasa yang berbeda-beda pada waktu dikenakan. Kadangkadang seperti mengenakan jas, tetapi setelah selesai pengurapannya pergi meninggalkan orang yang bersangkutan. Dan menurutnya, tidak seorangpun yang mampu bertahan terus dalam pengurapan Allah tersebut. Pengurapan tersebut seperti aliran listrik yang dapat mengakibatkan hal yang fatal. Orang yang mengalami pengurapan akan kehilangan kesadaran terhadap lingkungan di mana ia sedang berada namun dapat dikendalikan dan diatur sendiri apabila merasa tidak siap. ${ }^{52}$

\section{Pengurapan Bersifat Permanen}

Pengurapan itu bersifat permanen. Pengurapan yang diterima dari Allah itu terus berada dalam hidup orang percaya. Sifat permanen tersebut dapat diungkapkan oleh penggunaan tiga kata kerja dalam bagian ini.

Pertama, kata kerja ekhete. Dalam bahasa Yunani kata kerja tersebut digunakan dalam sebagai kata kerja kini, aktif, indikatif, orang kedua jamak dari kata $e k h \bar{o} .^{53}$ Artinya adalah mempunyai atau memiliki. Karena kata itu digunakan dalam kala kini, maka peristiwa tersebut sebenarnya sedang berlangsung. Penggunaan dalam kala kini indikatif berarti peristiwa tersebut sedang terjadi dilihat dari segi penulis dan merupakan tindakan yang sungguh real, yang benar-benar terjadi dalam hidup orang percaya. $^{54}$ Sebagai kata kerja transitif, kata tersebut sebenarnya dapat mempunyai arti mempunyai, memegang, memiliki, menangkap,

\footnotetext{
${ }^{51}$ Kenneth E. Hagin, Memahami Pengurapan Ilahi, (Jakarta: Yayasan Pekabaran Injil, 1990), 154.

${ }^{52}$ Ibid.

${ }^{53}$ Hans, Tenney, A Parsing, 428.

${ }^{54}$ Ray Summers, Bahasa Yunani Perjanjian Baru, pen. Petrus Maryono, Diktat Kuliah Sem. 6, 13.
}

menerima, atau mendapat. ${ }^{55}$ Baur's menjelaskan bahwa dalam bentuk aktif transitif dapat berarti mempunyai, memegang yang secara literal dapat berarti memegang dalam tangan, memegang sesuatu dalam tangannya sendiri. ${ }^{56}$

Kedua, kata kerja $\dot{\varepsilon} \lambda \alpha ́ \beta \varepsilon \tau \varepsilon$ (elabete). Kata elabete digunakan sebagai kata kerja aoris 2, aktif, indikatif, orang kedua jamak dari kata $\lambda \alpha \mu \beta \alpha ́ v \omega$ (lambano $).{ }^{57}$ Artinya adalah menerima ${ }^{58}$ dalam kata aoris, Yohanes menekan lamanya tindakan yang terjadi tetapi merupakan konotatif yaitu tindakan dilihat sebagai keseluruhan. Apabila dibandingkan dengan ayat 20 , dalam bagian ini adalah termasuk aoris ingresif yaitu menekan pemulaiannya dan terus berlangsung terjadi karena juga digunakan dalam kala kini dalam ayat 20. Pengurapan itu telah terjadi dan terus berlaku seterusnya sebagai suatu yang bersifat permanen. Dalam bentuk aktif maka dapat berarti mengambil, mengambil dari tangan, memegang dari, dan secara pasif dapat berarti menerima atau mendapatkan. ${ }^{59}$ Pengertian tersebut mengungkapkan makna pengurapan sebagai sesuatu yang diterima dengan sungguhsungguh telah terjadi tetapi akibatnya terus berlangsung terjadi dlam kehidupan.

Ketiga, kata $\mu \varepsilon ́ v \varepsilon ı$ (menei). Kata menei tersebut digunakan sebagai kata kerja kini, aktif, indikatif, orang ketiga tunggal dari kata $\mu \varepsilon ́ v \omega$ $\left(m e n o \overline{)}{ }^{60} \quad\right.$ Arti katanya adalah tinggal. ${ }^{61}$ Penggunaan dalam kala kini menyatakan bahwa pengurapan tersebut sedang berlangsung tinggal atau diam. Maka frasa dalam ayat 27 dapat diterjemahkan menjadi "...pengurapan itu yang sedang tinggal dari padaNya..." Pada waktu dilihat dari tindakan orang percaya yang menerima adalah dalam bentuk kala kini. Tetapi dari segi yang memberi pengurapan ternyata juga dalam kala kini. Hal itu menunjukkan bahwa pengurapan yang diterima oleh orang-orang percaya adalah sungguh-sungguh permanen, sebab pengurapan tersebut sedang tinggal tetap.

\footnotetext{
${ }^{55}$ Newman, 71.

${ }^{56}$ Bauer, Arndt, Gingrich, Greek Lexicon, 331.

${ }^{57}$ Hans, Tenney, A Parsing, 429.

${ }^{58}$ Newman, 106.

${ }^{59}$ Bauer, Arndt, Gingrich, Greek Lexicon, 464.

${ }^{60}$ Hans, Tenney, A Parsing, 429.

${ }^{61}$ Newman, 113.
} 
Kata kerja tersebut dapat menggambarkan pengertian mendiami, diam yaitu seseorang atau benda mendiami di mana dia atau benda tersebut berada, dalam bentuk kini dapat berarti mendiami dahulu, sekarang dan seterusnya untuk hidup. ${ }^{62}$ Pengurapan telah terjadi, sedang terjadi dan terus berlangsung untuk seterusnya secara terus menerus. C.C. Ryrie mengatakan bahwa pengurapan bukan sesuatu tindakan yang diulangi karena bentuk aoris, tetapi pengurapan itu tetap tinggal karena dalam bentuk kala kini. ${ }^{63}$ Pengurapan bersifat permanen.

\section{Pengurapan Mengajar Orang Percaya}

Pengurapan berguna untuk mengajar orang percaya. Hanya dalam bagian ini Alkitab menyatakan bahwa pengurapan itu berfungsi untuk mengajar.

\section{Arti Istilah Mengajar}

Dalam bahasa Yunani, kata yang digunakan adalah didaskei (didaskō). Digunakan secara mutlak istilah itu mempunyai arti mempertahankan suatu ceramah dengan yang lain; membimbing mereka, sesuai dengan tata cara yang berlaku ${ }^{64}$ Law Rence O. Richards menjelaskan bahwa istilah tersebut mempunyai banyak aplikasi, biasanya menekankan hubungan antara guru dan murid atau antara pelatih dan pesertanya termasuk di dalamnya memberikan informasi pelaksanaan, latihan baik pengetahuan maupun keahlian. ${ }^{65}$ Menurut Cremer, mengajar dapat berarti memberi pelajaran, membimbing ke jalan Tuhan sebagaimana pengajaran Tuhan Yesus dan dalam sasaran iman Kristen sesuai dengan ajaran Kristen. ${ }^{66}$ Didaskei dapat menyatakan pengertian umum, tetapi dipakai secara khusus dalam hubungannya dengan kehidupan menunjuk

\footnotetext{
${ }^{62}$ Ray Summers, 12.

${ }^{63}$ C.C. Ryrie, The Holy Spirit, (Chicago: Moody Press, 1965), 72.

${ }^{64}$ Joseh H. Thayer, Thayer's Greek-English Lexicon (Grand Rapids: Bakker Book House, 1977), 144.

${ }^{65}$ Richards, Dictionary of Bible Words, 590.

${ }^{66}$ Cremer, Biblico-Theological, 181.
}

kepada praktek hidup yang selaras dengan iman kepada Allah. Mengajar bukan sekedar menyampaikan ilmu yang bersifat teori, tetapi juga membimbing dan mengarahkan agar dapat menerapkan pengetahuan yang diterimanya dalam perjalanan hidupnya. Mengajar adalah membangun kebajikan melalui sumber kebenaran. ${ }^{67}$ Sasaran mengajar adalah perilaku hidup yang berdasarkan kebenaran pengetahuan yang dimiliki.

Dalam ayat 27, khususnya berkenaan dengan pengurapan istilah didaskei digunakan dalam bentuk sebagai kata kerja kini, aktif, indikatif, orang ketiga tunggal dari akar didaskō yang artinya mengajar. ${ }^{68}$ Dalam modus indikatif, istilah tersebut menunjuk tindakan tersebut merupakan realitas dari sudut pembicara. Dalam kala kini, menyatakan bahwa perbuatan tersebut sedang berlangsung dilakukan. Karena itu mengajar merupakan perbuatan yang bersifat kontinyu, terus menerus tanpa henti. Pengurapan itu membimbing, melatih, mendidik dan senantiasa memberikan pengetahuan tentang segala kebenaran. Perbuatan seperti itu hanya dilakukan oleh Roh Kudus dalam hidup orang percaya pada setiap saat tanpa ada batas waktunya.

\section{Isi Pengajaran}

Pengurapan itu Roh Kudus mengajar tentang segala sesuatu, kepada setiap orang percaya. Istilah yang diterjemahkan "tentang segala sesuatu" adalah berasal dari istilah Yunani $\pi \alpha ́ v \tau \omega v$ (pantōn), digunakan sebagai kata keterangan pronominal, genetif, netral, jamak. ${ }^{69}$ Istilah tersebut memiliki arti dasar pasti, tentu, sedapat mungkin. ${ }^{70}$ Istilah tersebut dapat mengandung arti segala maksud, secara tentu, pasti, mungkin. ${ }^{71}$ Didahului dengan kata depan $\pi \varepsilon \rho \grave{~(p e r i) ~ y a n g ~ a r t i n y a ~ t e n t a n g ~ a t a u ~ m e n g e n a i . ~}{ }^{72}$ Sehingga di dalam ayat 27 ini, frasa tersebut

\footnotetext{
${ }^{67}$ Merril Unger, Unger's Bible Dictionary, (Chicago: Moody Press, 1976), 1073.

${ }^{68}$ Hans, Tenney, A Parsing, 428.

${ }^{69}$ Friberg, Analytical, 724.

${ }^{70}$ Newman, 123.

${ }^{71}$ Bauer, Arndt, Gingrich, Greek Lexicon, 609.

${ }^{72}$ Newman, 130.
} 
dapat menjadi "tentang segala yang pasti atau tentu." Ini menyatakan bahwa apa yang diajarkan oleh pengurapan adalah hal-hal yang pasti dan tentu. Alford menyatakan bahwa mengetahui segala sesuatu, penuh dan pengetahuan sempurna dari kebenaran orang Kristen adalah ideal, lengkap, itu menjadi milik pengurapan ini. Secara pasti tidak dimengerti sebagai predikat nyata dari para pembaca, tetapi mengungkapkan penjelasan yang menunjuk segala sesuatu yang diperlukan untuk berbuat benar dalam masalah ini. Beberapa mengartikan segala sesuatu yang pasti untuk kehidupan Kristen dalam kesalehan. ${ }^{73}$

Pendapat lain menyatakan bahwa, ini bukan berarti maha tahu, tetapi pengetahuan penuh dan lengkap dari hal nyata, sebagai lawan dari pengetahuan yang tidak lengkap atau sepotongsepotong. ${ }^{74}$ Selanjutnya yang dimaksudkan segala sesuatu adalah termasuk kebenaran ajaran bahwa Yesus adalah Allah. Seseorang mengatakan bahwa segala sesuatu adalah menerangkan bahwa Yesus adalah Kristus Anak Allah yang hidup. ${ }^{75}$ Kebenaran tersebut adalah ajaran yang tentu dan pasti.

\section{Sifat Ajaran}

Ajaran yang disampaikan adalah benar dan tidak dosa. Kata yang digunakan adalah $\dot{\alpha} \lambda \eta \theta \dot{\varepsilon} \varsigma$ (alètes). Arti literalnya benar, selalu menyatakan yang sebenarnya, kejujuran, kelurusan hati, sejati atau tulen. ${ }^{76}$ Baur menambahkan arti yang sebenarnya, tulus hati, berbudi, budiman (Mat 22:26). ${ }^{77}$ Ajaran yang disampaikan oleh Kudus adalah ajaran yang mutlak benar. Pengurapan itu memberikan pengetahuan dan mengajar setiap orang percaya adalah segala sesuatu yang bersifat sangat benar, pasti dan tulen.

Sifat kebenaran ajaran juga dinyatakan dengan penggunaan istilah $\psi \varepsilon \tilde{\delta} \delta o \varsigma$ (pseudos) Kata ini mempunyai arti dusta, kebohongan,

\footnotetext{
${ }^{73}$ Henry Alford, The Greek New Testament, (Chicago: Moody Press, 1958), 451.

${ }^{74}$ Candlish, First Epistle of John, 168.

${ }^{75}$ Ibid., 169.

${ }^{76}$ Bauer, Arndt, Gingrich, Greek Lexicon, 36.

${ }^{77}$ Ibid.
}

pembohongan, tipuan, yang palsu. ${ }^{78}$ Baur menerangkan bahwa dalam penggunaannya kata tersebut menyatakan karakter roh-roh jahat. ${ }^{79}$ Dengan demikian istilah pseudos menyatakan suatu sifat yang sungguh-sungguh jahat sebagaimana karakternya roh jahat. Tetapi dalam penggunaannya kata tersebut didahului dengan kata ov̉к (ouk) yang merupakan kata keterangan penyangkal yang artinya tidak, digunakan dalam kalimat dengan kata kerja indikatif menuntut jawaban positif. $^{80}$ Istilah teserbut menyatakan suatu perbedaan yang sangat kuat. ${ }^{81}$ Jadi dalam hubungannya dengan penggunaan kata pseudos, menunjukkan bahwa ajaran yang diberikan oleh pengurapan adalah ajaran yang sungguh tidak dusta.

\section{Kesimpulan}

Pengurapan yaitu Roh Kudus bertugas mengajar setiap orang percaya. Pekerjaan ini berlangsung secara terus menerus tanpa mengenal waktu. Ia selalu mengajar segala sesuatu yang sifatnya sungguh-sungguh benar tanpa memiliki unsur kejahatan sedikitpun. Inilah yang menjadi prioritas pengajaran Yohanes kepada orang percaya dalam suratnya. Karena pengurapan tersebut sangat dibutuhkan dan Tuhan telah memberikannya kepada setiap orang percaya. Ia mengajar segala kebenaran yang bertumpu kepada kebenaran bahwa Yesus adalah Kristus Anak Allah.

\section{Kepustakaan}

Alkitab Kabar Baik untuk Masa Kini. Jakarta: Lembaga Alkitab Indonesia. 1978

Good News Bible Today's English Version. t.t: United Bible Societies. 1990

Aland, Kurt. The Greek New Testament, Ed. Mathew Black, Carlo M. Martini, Bruce M. Metzger, Aland Wikgren. Germany: Biblia-Druck BnbH Stuugart. 1983

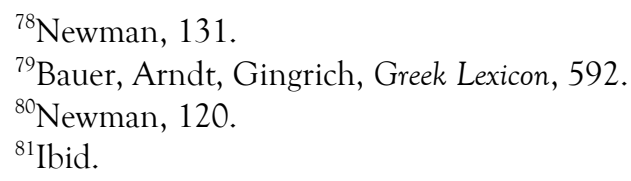


Aleksander, William. The Epistle St. John.

London: Hodder and Stoughton, t.t.

Alford, Henry The Greek New Testament. Chicago: Moody Press. 1958

Friberg, Barbara dan Timothy Friberg, Analytical Greek New Testament. Grand Rapids: Bakker Book House. 1982

Bauer, Walter, William F. Arndt, dan F. Wilbur Gingrich, Greek English Lexicon of The New Testament, Chicago: the University of Chicago Press. 1979

Burdick, Donald W. The Epistle of John. Chicago: Moody Press. 1970

Candlis, Robert S. The First Epistle of John. Grand Rapids: Zondervan Publishing House, t.t.

Cerullo, Morris. Urapan Baru, pen. Wimanjaya K. Liotohe. Jakarta: Yayasan Pekabaran Injil, t.t

Cremer, Hermann. Biblico-Theological Lexicon of The New Testament. Edinburg: T \& T Clark. 1985

Crichton, J.D. Sakramen dan Krisma. Yogyakarta: Kanisius. 1990

Girdlestone, Robert B. Synonims of The New Testament. Grand Rapids: Wm. B. Eerdmans Publishing Company. 1981

Gramberg, Ds. Th. B.W.G Tafsiran Surat-surat Yahya. Bandung: Nilakandi. 1967

Hagin, Kenneth E. Memahami Pengurapan Ilahi. Jakarta: Yayasan Pekabaran Injil. 1990

Hans, Nathan. dan Merrile C. Tenny, A Parsing Guide to The Greek of New Testament. Ontario: Herald Press. 1971

Herbert, Livingstone G. "anoint," Wiclif Bible Encyclopedia, Ed. Howard F., Vol. I. Chicago: Moody Press. 1975

Liddel, Henry Gerge dan Robert Scott, Greek English Lexicon. New York: American Book Company, t.t

Mariyanto, Ernest Persiapan Krisma Suci. Yogyakarta: Kanisius. 1985

Marshal, Howard I, Epistle of John, Gran Rapids: Zondervan Publishing House, 1988
Mitchel, John G. Fellowship Three Letters From John. Porland: Multnomah Press. 1979

Morris, Leon "Tafsiran I Yohanes," Tafsiran Alkitab Masa Kini. Jakarta: BPK Gunung Mulia. 1983

Muller, D. "Anoint," dalam The New International Dictionary of the New Testament Theology. peny. Collin Brown, Grand Rapids: Zondervan Publising House. 1975

Newman, Barclay M. Jr., Greek English Dictionary of The New Testament. London: United Bible Societies. 1971

Ricards, Lawrence O. Expository Dictionary of Bible Words. Grand Rapids: Zondervan Publising House. 1975

Richards, Dictionary of Bible Words

Ryrie, C.C. The Holy Spirit. Chicago: Moody Press. 1965

Sanders, J. Oswald. Roh Kudus Penolong Kita, pen. Alma E. Tobing. Jakarta: Badan Penerbit Kristen. 1965

Summers, Ray. Bahasa Yunani Perjanjian Baru, pen. Petrus Maryono, [Diktat Kuliah], Yogyakarta: STTII, t.t.

Thayer, Joseph H. Thayer's Greek-English Lexicon Grand Rapids: Bakker Book House. 1977

Unger, Merril. Unger's Bible Dictionary. Chicago: Moody Press. 1976

Vine, W.E. Expository Dictionary of The New Testament Words. Grand Rapids: Zondervan Publishing House, t.t.

Walvoord, John F. The Holy Spirit, Ed. 3. Grand Rapids: Zondervan Publishing House. 1988

Wuest, Kenneth S. Wuest's Word Studies, Vol. 3. Grand Rapids: Wm. B. Eerdmans Publishing Company. 1969 